\title{
Content Requirement Indicator
}

National Cancer Institute

\section{Source}

National Cancer Institute. Content Requirement Indicator. NCI Thesaurus. Code C114462.

An indication as to the necessity of a particular content type within a content model. 